\title{
Change in coccolith size and morphology due to response to temperature and salinity in coccolithophore Emiliania huxleyi (Haptophyta) isolated from the Bering and Chukchi seas
}

\author{
Kazuko Saruwatari ${ }^{1, a}$, Manami Satoh ${ }^{1,2}$, Naomi Harada ${ }^{3}$, Iwane Suzuki ${ }^{1,2}$, and Yoshihiro Shiraiwa S $^{1,2}$ \\ ${ }^{1}$ Faculty of Life and Environmental Sciences, University of Tsukuba, Tsukuba, 305-8572, Japan \\ ${ }^{2}$ CREST, Japan Science and Technology Agency (JST), Tsukuba, 305-8572, Japan \\ ${ }^{3}$ Research Institute for Global Change, Japan Agency for Marine-Earth Science and Technology (JAMSTEC), \\ Yokosuka, 237-0061, Japan \\ anow at: GIA Tokyo Godo Kaisha, Yamaguchi Building 7, 11F, 4-19-9 Taito, Taito-ku, Tokyo, 110-0016, Japan \\ Correspondence to: Yoshihiro Shiraiwa (emilhux @ biol.tsukuba.ac.jp)
}

Received: 30 September 2015 - Published in Biogeosciences Discuss.: 6 November 2015

Revised: 25 March 2016 - Accepted: 27 April 2016 - Published: 10 May 2016

\begin{abstract}
Strains of the coccolithophore Emiliania huxleyi (Haptophyta) collected from the subarctic North Pacific and Arctic oceans in 2010 were established as clone cultures and have been maintained in the laboratory at $15^{\circ} \mathrm{C}$ and $32 \%$ o salinity. To study the physiological responses of coccolith formation to changes in temperature and salinity, growth experiments and morphometric investigations were performed on two strains, namely MR57N isolated from the northern Bering Sea and MR70N at the Chukchi Sea. This is the first report of a detailed morphometric and morphological investigation of Arctic Ocean coccolithophore strains. The specific growth rates at the logarithmic growth phases in both strains markedly increased as temperature was elevated from 5 to $20^{\circ} \mathrm{C}$, although coccolith productivity (estimated as the percentage of calcified cells) was similar at $10-20 \%$ at all temperatures. On the other hand, the specific growth rate of MR70N was affected less by changes in salinity in the range $26-35 \%$, but the proportion of calcified cells decreased at high and low salinities. According to scanning electron microscopy (SEM) observations, coccolith morphotypes can be categorized into Type B/C on the basis of their biometrical parameters. The central area elements of coccoliths varied from thin lath type to well-calcified lath type when temperature was increased or salinity was decreased, and coccolith size decreased simultaneously. Coccolithophore cell size also decreased with increasing temperature, although the variation in cell size was slightly greater at the lower salinity
\end{abstract}

level. This indicates that subarctic and arctic coccolithophore strains can survive in a wide range of seawater temperatures and at lower salinities with change in their morphology. Because all coccolith biometric parameters followed the scaling law, the decrease in coccolith size was caused simply by the reduced calcification. Taken together, our results suggest that calcification productivity may be used to predict future oceanic environmental conditions in the polar regions.

\section{Introduction}

Sea ice reduction due to global warming has become a major concern in the Arctic and Subarctic regions due to its induction of various environmental changes (e.g., Post et al., 2013; Wassmann et al., 2011). As a constituent of oceanic ecosystems, phytoplankton are important primary producers and key markers for understanding changes in the oceanic environment (e.g., Fujiwara et al., 2014; Harada et al., 2012). A large-scale change in the oceanic environment was observed as a climatic regime shift in the subpolar Pacific region, such as the Bering Sea, in 1976-1977 (Mantua et al., 1997). Siliceous diatoms are the dominant primary producers in that location (Tsunogai et al., 1979), but an increase in the population of the calcareous haptophyte Emiliania huxleyi is suggested by the alkenone biomarkers preserved in the oceanic sediments (Harada et al., 2012). The reduction of sea 
ice in the northern Chukchi Sea from 2008 to 2010 has influenced the phytoplankton distribution pattern (Fujiwara et al., 2014). The shorter sea ice retreat in 2008 resulted in haptophyte dominance in warm water $\left(\sim 5^{\circ} \mathrm{C}\right)$, while the longer sea ice retreat in 2009 and 2010 led to prasinophytes predominating in cold water $\left(<0^{\circ} \mathrm{C}\right)$. Thus, the composition of marine phytoplankton communities is sensitive to environmental changes in oceanic environments.

The coccolithophore E. huxleyi, which belongs to the family Noëlaerhabdaceae, order Isochrysidales, class Prymnesiophyceae in the Haptophyta, is one of the most investigated phytoplankton species because of its marked ability to fix carbon dioxide, which enables it to produce considerable quantities of biomass during blooms, having a marked impact on the global climate. It is broadly distributed from the equator to subpolar oceans (e.g., Beaufort et al., 2011; Hagino et al., 2011; Liu et al., 2009), and produces calcified scales called coccoliths. The distal and proximal shield elements, central opening size, and calcite crystals of coccoliths exhibit complex morphologies.

Young et al. (2003) systematized the morphotypes of coccoliths of coccolithophores. In E. huxleyi, three wellestablished morphotypes (Types A, B, and C) and two additional morphotypes (Types $\mathrm{B} / \mathrm{C}$ and $\mathrm{R}$ ) were categorized in addition to E. huxleyi var. corona. Hagino et al. (2011) classified coccolith morphotype into seven types, and further grouped into the four cross-sectioned types: (1) Type A and Type $\mathrm{R}$ with moderate to heavily calcified distal shields that are larger than the proximal shields, a grilled central area, and a length of distal shield (LDS) less than $4 \mu \mathrm{m}$; (2) $E$. huxleyi var. corona, whose distal and proximal shields and central area are similar to those of Group (1) but whose central tube elements are elevated and whose LDS is 3.5$4.5 \mu \mathrm{m}$; (3) Type B, Type B/C, and Type C, with lightly calcified distal shields that are smaller than the proximal shields and a fully calcified central area but whose LDSs change from larger $(>4 \mu \mathrm{m})$ to smaller $(<3.5 \mu \mathrm{m})$; and (4) Type $\mathrm{O}$, whose distal and proximal shields are similar to those of Group (3) but have an opened central area and lack calcification. Young and Ziveri (2000) and Poulton et al. (2011) estimated the calcite contents of Types A, B, and B/C. Because the estimation is proportional to the cube of the coccolith shield length, calcite contents were in the following order from highest to lowest: Type B, Type A, and Type B/C.

The oceanographic distribution of Type A and Type C, defined by Young and Westbroek (1991), approximately corresponds to warm- and cold-water types, described by McIntyre and Bé (1967), respectively, although Type C has not always been reported in cold-water environments (Young and Westbroek, 1991; Hagino et al., 2011). Recent studies performed in the Southern Ocean also suggest that coccolith morphotypes are distinct ecotypes in the coccolithophore $E$. huxleyi because Type $\mathrm{A}$ is abundant in warm and nutrientpoor water while Type $\mathrm{B} / \mathrm{C}$ is abundant in cold and nutrientrich water (Poulton et al., 2011).
The relationships between coccolith size and various environmental factors, such as growth phase, temperature, salinity, and nutrients, have been investigated using $E$. huxleyi cultures (e.g., Watabe and Wilbur, 1966; Young and Westbroek, 1991; Paasche, 2001; Fielding et al., 2009). Young and Westbroek (1991) investigated the size of coccolith at the end of growth phase, resulting that Type A coccolith is normally smaller than Type B coccolith. However, both types showed an overlapping size distribution and also a Type A strain (strain L) unusually produces large coccolith in the late stationary growth phase. Watabe and Wilbur (1966) reported that coccolith size decreased with increasing temperature at the end of growth phase; other authors have reported similar results for coccolithophore cell size (Sorrosa et al., 2005; De Bodt et al., 2010). Regarding the effects of salinity, Paasche et al. (1996) first reported that lower salinity was associated with a decrease in the length of the distal and proximal shield elements. Fielding et al. (2009) reported a linear correlation between salinity and the length of the distal shield. Phosphorous deficiency may induce overcalcification, while nitrogen limitation may result in the production of less-calcified coccoliths (Paasche, 1998).

In this study, the effects of growth phase, temperature, and salinity on coccolithophore growth and coccolith morphology investigated by scanning electron microscopy (SEM) photometry were examined in two newly established strains of E. huxleyi isolated from the Bering Sea and Chukchi Sea during the MIRAI cruise (MR10-05) in 2010. There were marked changes in coccolith size and productivity (i.e., the percentage of calcified cells); we discuss the implications of this in relation to calcification productivity under future oceanic environments in the Arctic Ocean.

\section{Materials and methods}

The samples were taken during the R/V MIRAI Arctic Ocean research cruise (MR10-05) organized by the Japan Agency for Marine-Earth Science and Technology (JAMSTEC) in August-October 2010. Strain names established as clones of the coccolithophore E. huxleyi (Lohman) Hay \& Mohler were MR57N and MR70N, respectively. Those strains, MR57N and MR70N, were isolated from seawater samples obtained at $56^{\circ} 58^{\prime} \mathrm{N}, 167^{\circ} 11^{\prime} \mathrm{W}$ (station: s15), and $4 \mathrm{~m}$ water depth in the Bering Sea (sampling date: 15 October 2010; in situ temperature and salinity: not recorded exactly, but sea surface temperature (SST) at the nearest point determined on 14 October 2010 is $3.6^{\circ} \mathrm{C}$ ) and at $69^{\circ} 99^{\prime} \mathrm{N}$, $168^{\circ} \mathrm{W}$ (station: 166), and $10 \mathrm{~m}$ water depth in the Chukchi Sea (in situ temperature and salinity: $5.73^{\circ} \mathrm{C}$ and $31.22 \%$, respectively), respectively.

Water samples were collected by a water-sampling system with CTD (conductivity-temperature-depth profiler, $12 \mathrm{~L} \times 36$ bottles, SBE911 Plus/Carousel, Sea-Bird Electronics, Inc., USA) and also a continuous monitoring system set 
at sea surface level in the monitoring laboratory on R/V MI$R A I$. Water samples were filtrated through a $300 \mu \mathrm{m}$ nylon mesh and then the filtrate water was used for preparing seawater for algal culture by mixing with seawater enriched with Erd-Schreiber's medium (ESM) containing $10 \mathrm{nM}$ sodium selenite, instead of soil extracts usually contained (Danbara and Shiraiwa, 1999).

Those water samples had been maintained under weak illumination with a regime of light/dark $(16 \mathrm{~h} / 8 \mathrm{~h})$ at light intensity of $10 \mu \mathrm{mol}$ photons $\mathrm{m}^{-2} \mathrm{~s}^{-1}$ and at $4{ }^{\circ} \mathrm{C}$ on board. For isolation of coccolithophores, algal samples highly diluted with ESM seawater had been maintained in microplates for about 2 months on board, according to the so-called dilution method. Afterwards, tens of single cells of coccolithophores were isolated from the seawater sample by being picked up under a microscope.

The strains were established as clones according to our previous report (Satoh et al., 2013) at the University of Tsukuba, Japan, as described above, but those are not axenic cultures. Currently, both strains are stored in the algal culture collection of the National Institute for Environmental Studies (NIES), Tsukuba, Japan (strain numbers: NIES3366 and NIES3362, respectively).

Stock cultures of the MR57N and MR70N strains were maintained in the MNK medium (Noël et al., 2004) in a $100 \mathrm{~mL}$ glass Erlenmeyer flask with an air-permeable, porous, silicone cap under a light/dark regime of $16 \mathrm{~h} / 8 \mathrm{~h}$. Temperature was maintained at $4{ }^{\circ} \mathrm{C}$ in a water bath equipped with a thermocontroller. The cultures were illuminated by a white $20 \mathrm{~W}$ fluorescent lamp at a light intensity of about $40 \mu \mathrm{mol}$ photons $\mathrm{m}^{-2} \mathrm{~s}^{-1}$. As controls, two other strains of E. huxleyi obtained from the culture collections were used. One was strain MS1 of coccolith morphotype A (Hagino et al., 2011), obtained from The Roscoff Culture Collection (RCC1226; Station Biologique De Roscoff, Roscoff, France). The second was strain NIES1311 of coccolith morphotype O (Hagino et al., 2011), obtained from Culture Collection of the National Bioresource Project in NIES at the Bering Sea in August 2002. Stock cultures of both strains were maintained at $15^{\circ} \mathrm{C}$ in an incubator (MLR-350T; Panasonic Healthcare, Tokyo, Japan) under fluorescent lamps at a light intensity of 32-34 $\mu \mathrm{mol}$ photons $\mathrm{m}^{-2} \mathrm{~s}^{-1}$ before use in experiments.

Algal cells were transferred from stock cultures to precultures and then grown to the stationary phase under the same conditions used for the subsequent experimental culture. Cultures were involved in three cycles of dilution and growth (three generations) to enable cells to acclimate to the experimental temperature or salinity conditions. Growth experiments were independently performed in triplicate in $200 \mathrm{~mL}$ glass conical flasks containing $100 \mathrm{~mL}$ culture medium. The culture medium was artificial seawater Marine Art SF-1 enriched with ESM micronutrient enrichments in which soil extracts were replaced with $10 \mathrm{nM}$ (final concentration) sodium selenite (Danbara and Shiraiwa,
1999). Salinity was adjusted to 26,32 , or $35 \%$, while $\mathrm{pH}$ was fixed at 8.2. Final concentrations of nitrate and orthophosphates in the medium were $1.4 \mathrm{mM}$ and $28.7 \mu \mathrm{M}$, respectively. Temperature was set at various values using an incubator (TG-180-5L, Nippon Medical \& Chemical Instruments, Osaka, Japan). The culture was illuminated using fluorescent lamps under an incident photon flux density of $100 \mu \mathrm{mol}$ photons $\mathrm{m}^{-2} \mathrm{~s}^{-1}$ with a light/dark regime of $16 \mathrm{~h} / 8 \mathrm{~h}$. The growth rate at each temperature was calculated as the average value of triplicate experiments, and the error bars indicated the minimum and maximum values.

At intervals, $1.5 \mathrm{~mL}$ cell suspension was harvested after gentle shaking every 2 days during the light period for enumeration of cells and preparation of samples for SEM observation. Cell counts were performed twice under a polarized microscope (BX-50, Olympus, Tokyo, Japan). The numbers of cells in $10 \mu \mathrm{L}$, including both calcified and noncalcified (naked) cells, were determined using cell counting glass plate under the microscope and then the total numbers of cells were extrapolated from them. Samples for SEM observation were prepared by dropping $100 \mu \mathrm{L}$ algal suspension on polycarbonate filters (ATTP04700, Isopore membrane filter with $0.8 \mu \mathrm{m}$ pore size, Millipore). After removing salts from the medium by washing with distilled water, the polycarbonate filters were dried on Whatman Nucleopore ${ }^{\mathrm{TM}}$ filters (GE Healthcare Japan, Tokyo, Japan). The polycarbonate filters with attached cells were mounted on SEM holders using carbon paste and then coated with Pt-Pd (E-1045, Hitachi Power Solutions, Ibaraki, Japan) for SEM observation (6330F, JEOL, Tokyo, Japan).

As first, the sizes of cell and coccolith of MR57N strain were investigated at the different timing of the growth at each different temperature. Based on the first experimental results, the other morphometric experiments of other strains were performed at the early timing of the logarithmic growth condition.

For the photometric analyses, about 100 coccolithophore cells were observed by SEM per sample, and image analyses were performed using Image $\mathbf{J}$ (Image Processing and Analysis of Java: http://rsb.info.nih.gov/ij/).

\section{Results}

The MR57N and MR70N strains showed similar growth properties at 5 to $20^{\circ} \mathrm{C}$ (Fig. 1, Table 1). The final cell densities obtained at the stationary growth phase were about $1 \times 10^{7}$ cells $\mathrm{mL}^{-1}$ for all E. huxleyi strains, suggesting that growth limitation during the stationary growth phase was due to nutrient depletion (Fig. 1, Table 1). The specific growth rate ( $\mu$ value) of MR70N increased linearly with temperature from 5 to $20^{\circ} \mathrm{C}$. The $\mu$ value at $5^{\circ} \mathrm{C}$ $\left(\mu=0.31-0.29 \mathrm{~d}^{-1}\right)$ was about $40 \%$ lower than that at $20^{\circ} \mathrm{C}$ $\left(\mu=0.78-0.86 \mathrm{~d}^{-1}\right)$. The $\mu$ value at $20^{\circ} \mathrm{C}$ was similar to that of other strains, such as MS1 and NIES1311, isolated 
Table 1. Temperature effect on specific growth rates $(\mu)$ of various strains of the coccolithophore E. huxleyi isolated from the Bering Sea (MR57N), the Arctic Sea (MR70N), the North Sea (MS1), and the Bering Sea (NIES1311). In the whole culture, numbers of calcified cells with coccoliths and naked cells without coccolith were separately counted under microscope. Salinity of the medium was $32 \%$. All values are average of three separate experiments $(n=3)$.

\begin{tabular}{|c|c|c|c|c|c|c|c|c|c|c|}
\hline \multirow{3}{*}{$\begin{array}{l}\text { Growth temperature } \\
\text { Strains }\end{array}$} & \multicolumn{10}{|c|}{ Specific growth rate $\left(\mu \mathrm{d}^{-1}\right)$ at } \\
\hline & \multicolumn{4}{|c|}{$20^{\circ} \mathrm{C}$} & \multicolumn{2}{|c|}{$15^{\circ} \mathrm{C}$} & \multicolumn{2}{|c|}{$10^{\circ} \mathrm{C}$} & \multicolumn{2}{|c|}{$5^{\circ} \mathrm{C}$} \\
\hline & MR57N & MR70N & MS1 & NIES1311 & MR57N & MR70N & MR57N & MR70N & MR57N & MR70N \\
\hline Whole culture & 0.78 & 0.84 & 0.76 & 0.63 & 0.54 & 0.53 & 0.47 & 0.44 & 0.30 & 0.29 \\
\hline Calcified cells & 0.64 & 0.66 & 0.65 & 0.81 & 0.39 & 0.34 & 0.38 & 0.34 & 0.22 & 0.30 \\
\hline Naked cells & 0.82 & 0.99 & 0.89 & 0.52 & 0.61 & 0.60 & 0.58 & 0.47 & 0.32 & 0.28 \\
\hline
\end{tabular}

Table 2. Effect of salinity on growth rates of the coccolithophore $E$. huxleyi isolated from the Arctic Sea (MR70N). For other conditions, see Table 1.

\begin{tabular}{lccc}
\hline & \multicolumn{3}{c}{$\begin{array}{c}\text { Specific growth rate }\left(\mu \mathrm{d}^{-1}\right) \\
\left(\text { at } 15^{\circ} \mathrm{C}\right)\end{array}$} \\
& \multicolumn{3}{c}{ with salinity of } \\
\cline { 2 - 4 } & $26 \% 0$ & $32 \% 0$ & $35 \% 0$ \\
\hline Whole culture & 0.60 & 0.53 & 0.58 \\
Calcified cells & 0.42 & 0.34 & 0.32 \\
Naked cells & 0.60 & 0.60 & 0.58 \\
\hline
\end{tabular}

from the North Sea of the Atlantic Ocean and the Bering Sea and which exhibited values of 0.76 and $0.63 \mathrm{~d}^{-1}$, respectively. However, both the MS1 and NIES1311 strains did not grow at $<10^{\circ} \mathrm{C}$ (data not shown). The growth rates of whole cells of the MR70N strain at salinities of 26 and $35 \%$ at $15{ }^{\circ} \mathrm{C}$ were higher $\left(\mu=0.6\right.$ and $\left.0.58 \mathrm{~d}^{-1}\right)$ than those at $32 \%$ o $\left(\mu=0.53 \mathrm{~d}^{-1}\right.$; Table 2$)$. The growth rate of calcified cells increased with decreasing salinity from 0.32 to $0.42 \mathrm{~d}^{-1}$.

The effect of temperature on calcification, namely coccolith productivity, was examined by monitoring the number of calcified and non-calcified cells. Interestingly, the numbers of calcified cells in cultures of strains MR57N and MR70N were lower than those of non-calcified (naked) cells with the approximate proportion of 8 to $26 \%$ (Fig. 1 and Table 1). Compared to the MR57N and MR70N strains, about half (56-41\%) of MS1 and NIES1311 cells were calcified, indicating that $E$. huxleyi MR strains were less extensively calcified under the culture conditions. The numbers of calcified cells decreased markedly to $1 \%$ at both lower and higher salinities (Table 2).

Morphometric parameters and the morphological properties of the newly established Bering and Chukchi strains MR57N and MR70N changed during culture under various conditions (Figs. 2-3). All measured parameters of cells and coccoliths of the MR57N and MR70N strains increased with decreasing temperature (Fig. 2d-g). The MS1 and NIES1311 strains cultured at $20^{\circ} \mathrm{C}$ showed similar morphometric parameters, with the difference that the number of distal shield elements in MS1 was slightly lower than that in NIES1311 (Fig. 2g). MR57N and MR70N cells exhibited reductions in size from 5.3-5.5 to 4.4-5.0 $\mu \mathrm{m}$ as temperature increased from 5 to $20^{\circ} \mathrm{C}$ (Fig. 2d). Moreover, average LDS values decreased from $4.10-4.15 \mu \mathrm{m}$ at $5^{\circ} \mathrm{C}$ to $3.09-3.32 \mu \mathrm{m}$ at $20^{\circ} \mathrm{C}$ (Fig. 2e). The LDS values of the MS1 and NIES1311 strains at $20^{\circ} \mathrm{C}$ were similar to those of MR70N, whereas MR57N exhibited slightly higher values (Fig. 2e). The length of the inner central area (LICA) values of the MR57N and MR70N strains were almost identical and decreased with increasing temperature. The LICA values of the MS1 and NIES1311 strains were identical (about $1.4 \mu \mathrm{m}$ on average), but smaller than those of the MR strains $(1.6-1.7 \mu \mathrm{m}$ on average) at $20^{\circ} \mathrm{C}$ (Fig. 2f). The number of distal shield elements decreased with increasing temperature; this trend was similar to the changes in LICA and LDS in the MR57N and MR70N strains. At $20^{\circ} \mathrm{C}$, the numbers of distal shield elements in the MR57N and MR70N strains (37 and 35 on average, respectively) were greater than those in the MS1 and NIES1311 strains (30 and 32 on average, respectively; Fig. 2g). Consequently, cell and coccolith sizes of both MR strains were larger than those of the MS1 and NIES1311 strains at $20^{\circ} \mathrm{C}$.

Figure 3 shows the effects of increasing temperature (5$20^{\circ} \mathrm{C}$ ) on the relationship between cell diameters and LDS in E. huxleyi strains MR57N and MR70N cultured at a salinity of $32 \%$. The sizes of both cells and coccoliths increased linearly with increasing temperature (Fig. 3a). The distribution of coccolith sizes overlapped with those of Types B, B/C, and C, which were defined previously by Young et al. (2003) and Hagino et al. (2011; Fig. 3a). Figure $3 b$ is drawn as the schematic model of the correlated cell and coccolith sizes at the higher and lower temperature.

The morphology of coccoliths of both MR strains was characterized by fragile/delicate distal shield elements, a completely calcified or often lath-like central area element and a proximal shield element larger than the distal shield element (Fig. 2a-c). In addition, the LDS was 3-5 $\mu \mathrm{m}$ (3.3$4.3 \mu \mathrm{m}$ on average) in cells cultured at various temperatures (Figs. 2e, 3a). Based on these properties, both the MR57N and MR70N strains can be classified as being of the Type 
(a)

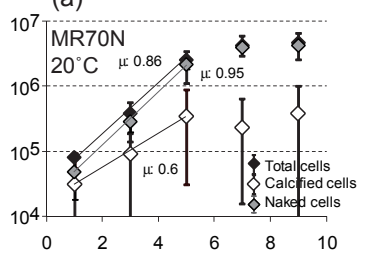

(b)
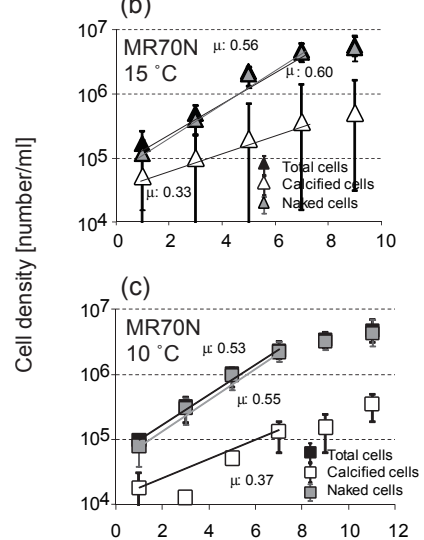

$10^{7}(\mathrm{~d})$

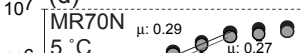

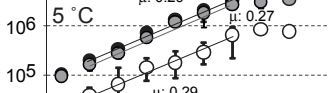

OP $4: 0.29$
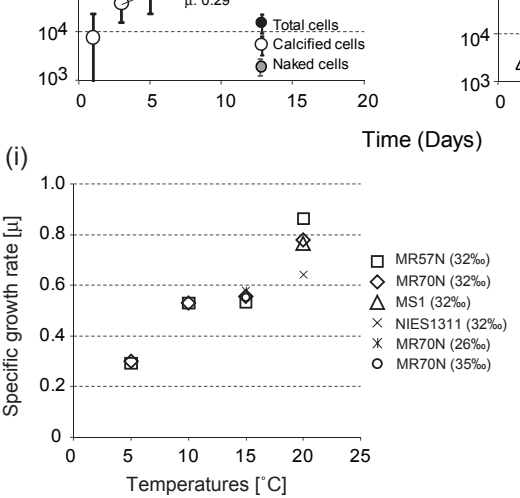

Figure 1. Growth responses of an Arctic strain of E. huxleyi (strain MR70N) to changes in temperature and salinity, (a) growth curves of E. huxleyi at $20^{\circ} \mathrm{C}$ and a salinity of $32 \%$; (b) at $15^{\circ} \mathrm{C}$; (c) at $10^{\circ} \mathrm{C}$; (d) at $5{ }^{\circ} \mathrm{C}$; (e) growth curves of E. huxleyi strain MS1 at $20^{\circ} \mathrm{C}$; (f) growth curves of E. huxleyi strain NIES1311 at $20^{\circ} \mathrm{C}$; (g) growth curves of E. huxleyi strain MR70N at 26\%o salinity; (h) growth curves of E. huxleyi strain MR70N at 35\%o salinity. Solid, gray, and white symbols indicate whole culture (naked + calcified cells), non-calcified (naked), and calcified cells, respectively. (i) Effect of growth temperature on the specific growth rates of whole cells of E. huxleyi strains MR57N (squares), MR70N (diamonds), MS1 (triangles), and NIES1311 (crosses) at 32\%o, and MR70N at 26\%o (asterisks) and 35\%o (circles). For $\mu$ values, see graphs (a-h) and Table 1.
B/C morphotype, which was defined previously by Young et al. (2003) and Hagino et al. (2011).

To further confirm the morphotype of MR strains, Fig. 4 shows the relationship between the width of the distal shield elements and LDS. The width of the distal shield elements for all strains was less than $0.1 \mu \mathrm{m}$ from the range that fits within the plots of morphotype B/C determined by Cook et al. (2011). However, the width of the distal shield element in MS1 was larger than that of the other strains. Since MS1 is categorized as morphotype A, the dashed line in Fig. 4 might be the boundary between the morphotype A and morphotype B reported by Young and Westbroek (1991).

Because of the SEM observation of several central area morphologies, we categorized coccolith and coccolithophore cell morphotypes into four submorphotypes (Types I-IV) and malformed types according to their morphological properties observed by SEM of E. huxleyi strains MR70N (Fig. 5). The definitions follow: Type I (Fig. 5a1 and a2), the central area elements are completely calcified; Type II (Fig. 5b1 and b2), the central area elements are partially calcified or exhibit lath-like structure similar to the central area of morphotype B or C classified by Young et al. (2003) and Young and Westbroek (1991); Type III (Fig. 5c1 and c2), the central area is open with a hole in the center but the marginal area is well calcified without spaces; Type IV (Fig. 5d1 and d2), the central area is open with a hole in the center and the other marginal area is not well calcified, showing lath-like structure; malformed type (Fig. 5e2), the distal shield elements are not well calcified, showing an irregular morphology. Next, we designated "cell morphotypes" according to coccolith type, which comprised the majority of cells (Fig. 5a3-e3). For instance, Type I cells consisted of about 60-80\% of Type I coccoliths and 20-40\% of the other types of coccolith; therefore, small amounts of various types of coccolith are produced by a single cell (Fig. 5a4). In contrast, cells with high proportions of coccoliths of various types were defined as "mixed types" to evaluate the proportion of the coccolithophore submorphotypes at each experiment (Fig. 6).

Figure 6 shows the proportion of submorphotypes of coccolithophore cells in E. huxleyi MR57N, MR70N, MS1, and NIES1311 strains which were harvested at the early logarithmic growth phase. Strains MR57N and MR70N were nearly $100 \%$ Type II cells at $5{ }^{\circ} \mathrm{C}$; however, this proportion decreased with increasing temperature, which was accompanied by an increase in the proportion of Type I cells (Fig. 6). At $20^{\circ} \mathrm{C}$, Type I cells made up 25 and $35 \%$ of strains MR57N and MR70N, respectively. About $10 \%$ of cells were classified as malformed or mixed-type coccoliths. However, only 7 and $85 \%$ were Type I and II cells, respectively, in the MS1 strain cultured at $20^{\circ} \mathrm{C}$. On the other hand, $85 \%$ of NIES1311 cells were Type O (defined by Hagino et al., 2011), the coccoliths of which have no central area element. In addition, about $10 \%$ were malformed or incomplete coccoliths (Fig. 6). 

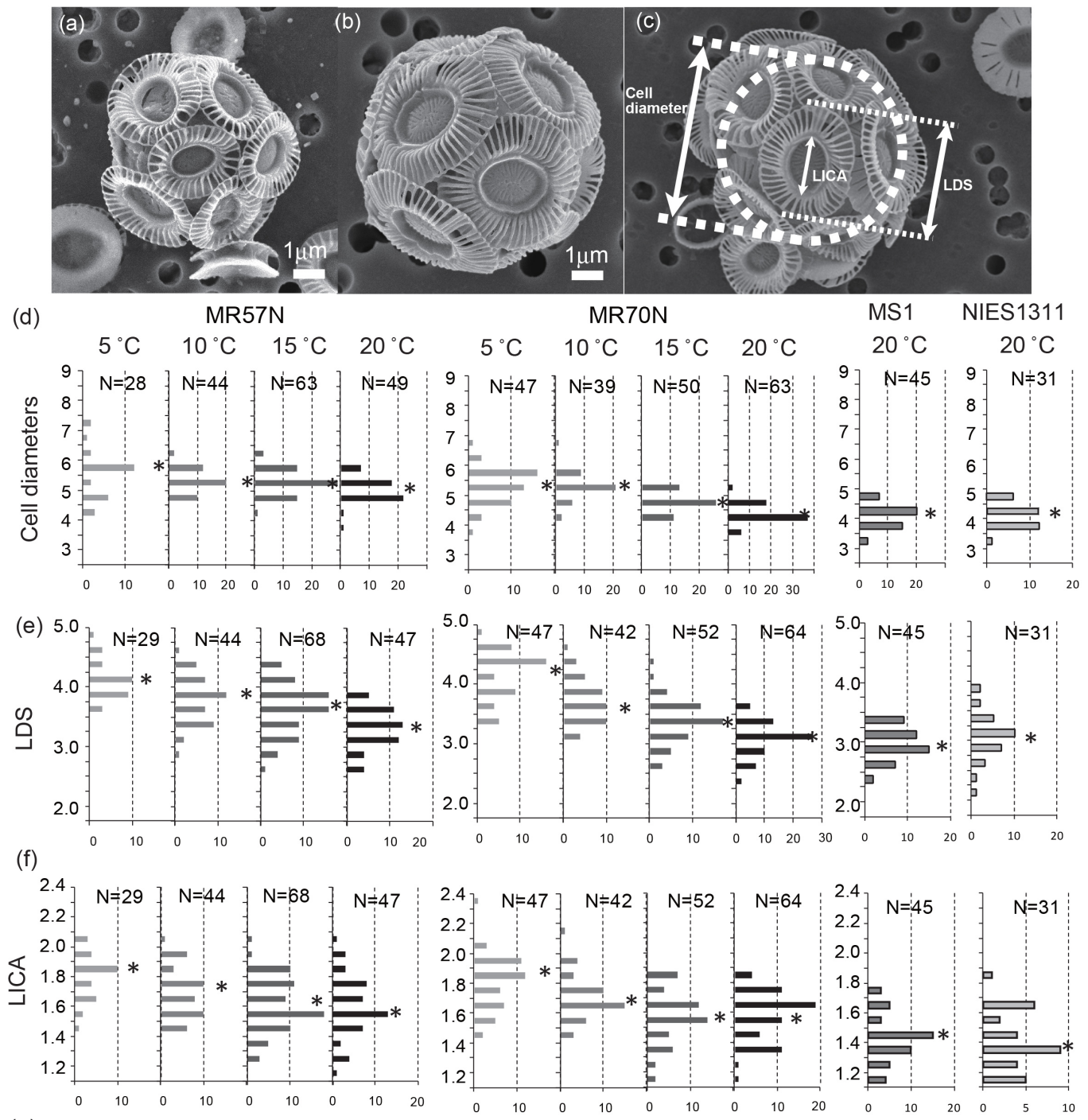

(g)
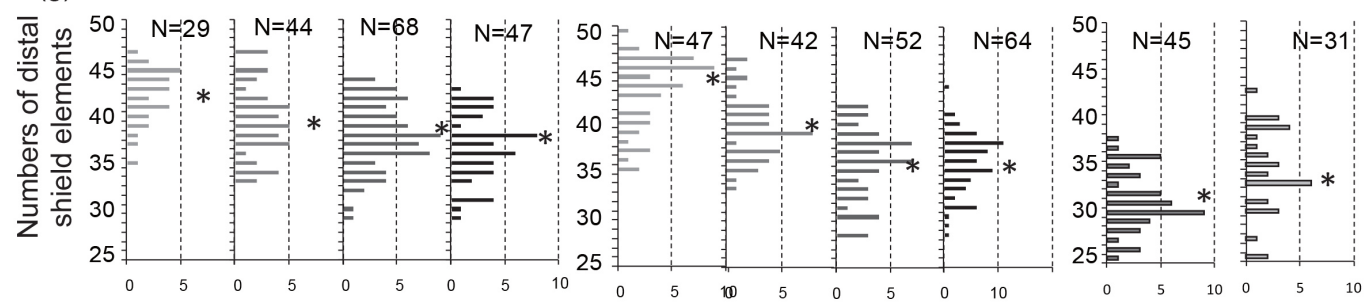

Frequency

Figure 2. Effects of temperature on cell morphology. (a) SEM images of strain MR70N grown at $20^{\circ} \mathrm{C}$; (b) SEM images of strain MR70N grown at $5{ }^{\circ} \mathrm{C}$. (c) Definitions of morphometric parameters of E. huxleyi cells: (d) cell diameter; (e) longer distal shield length (LDS); (f) long axis length of the inner central area (LICA); and (g) the numbers of distal shield elements in a coccolith. The MR1 and NIES1311 strains grown at $20^{\circ} \mathrm{C}$ were used as controls. Asterisk (*) and $\mathrm{N}$ indicate the average value of each histogram and the number of samples determined, respectively.

When the cell growth stage proceeded to the late logarithmic phase, the proportions of submorphotypes were changed even in the same strain of E. huxleyi MR57N, as shown in Fig. 7. Cell diameter and LDS were increased proportionally by decreasing growth temperature, but no obvious change was observed by proceeding growth phase from the early to late logarithmic phases (Fig. 7a). In cells at the early logarithmic phase, Type II morphotypes were dominant at $5{ }^{\circ} \mathrm{C}$ 


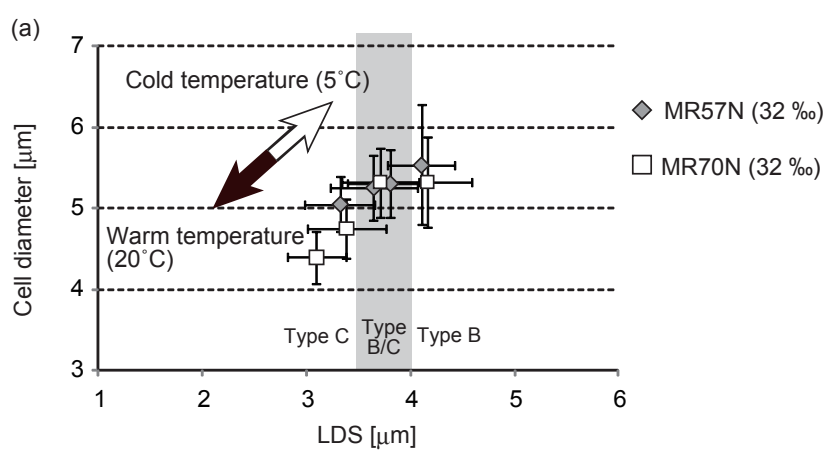

(b)

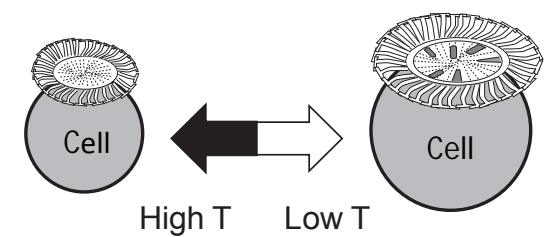

Figure 3. (a) Changes in cell diameters and LDS in E. huxleyi strains MR57N and MR70N grown at 5, 10, 15, and $20^{\circ} \mathrm{C}$; (b) schematic models of images of cell and coccolith sizes according to growth temperature. Descriptions of Type B, B/C, and C indicate the LDS range of coccoliths of the morphotypes defined by Young et al. (2003) and Hagino et al. (2011).

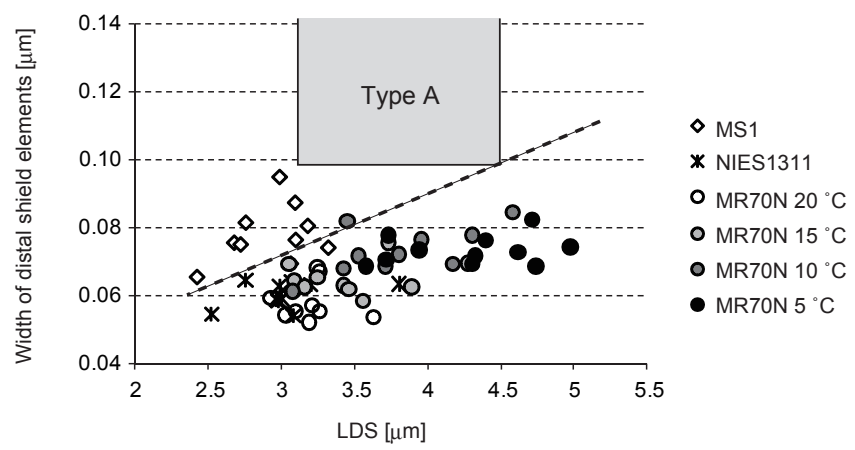

Figure 4. Relationship between the width of the distal shield elements and LDS in E. huxleyi strain MR70N grown at 5, 10, 15, and $20^{\circ} \mathrm{C}$ and strains MS1 and NIES1311 grown at $20^{\circ} \mathrm{C}$. Area described with Type A indicates an area where sizes of Type A coccoliths distribute in the literature (Young and Westbroek, 1991; Cook et al., 2011).

but was substituted gradually with other morphotypes, especially Type I, by increasing growth temperature (Fig. 7b). On the other hand, Type II was dominant at $5{ }^{\circ} \mathrm{C}$ but was substituted by Type IV, which became dominant at $20^{\circ} \mathrm{C}$ in cells in the late logarithmic phase (Fig. 7c)

The effects of salinity on coccolith morphometry and morphotype in strain MR70N at $15^{\circ} \mathrm{C}$ were shown in Fig. 8 . The changes in the average LDS values ranged from 3.38 to $3.53 \mu \mathrm{m}$ among salinities of 26, 32, and 35\%o (Fig. 8a), but cell diameters were larger at $26 \%$ salinity (Fig. 8b). Submorphotypes of MR70N cells were greatly affected by salin- ity during growth. The Type I and II subtypes made up about 40 and $25 \%$, respectively, of all cells grown at a salinity of $26 \%$, but changed to about 2 and $70 \%$ at a salinity of $35 \%$ o (Fig. 8c). As shown in Fig. 8d, there was a positive linear relationship between cell diameter and LDS, and cell diameter increased without change in LDS with decreasing salinity. One explanation for this relationship is that it might be caused by the increase of cell diameter due to the increase of coccolith layers surrounding the cell.

\section{Discussion}

\subsection{Effects of temperature on growth rate, coccolith morphometry, and morphology}

The MR57N and MR70N strains exhibited growth at $5{ }^{\circ} \mathrm{C}$ with $\mu$ values of about $0.3 \mathrm{~d}^{-1}$ (Fig. 1); in contrast, other strains such as MS1 and NIES1311 did not grow. On the other hand, the $\mu$ values at $20^{\circ} \mathrm{C}$ of the four strains isolated from cold-water areas were identical $\left(0.8 \mathrm{~d}^{-1}\right)$. The ability of microalgae to grow at low temperatures may be mostly due to their cold-water origin, as reported by Conte et al. (1998). Therefore, the ability of both MR strains to grow at $5{ }^{\circ} \mathrm{C}$ seems to be due to their genetically fixed ability because their cold tolerance was maintained even after long-term storage as stock cultures at $15^{\circ} \mathrm{C}$ (see materials and methods). This temperature dependency of the two MR strains is similar to that of E. huxleyi strain L (NIOZ culture collection, Texel; originally isolated from the Oslo Fjord) reported by van Rijssel and Gieskes (2002), although the specific growth rate at $4{ }^{\circ} \mathrm{C}$ was $0.12 \mathrm{~d}^{-1}$, which is half that of the MR strains. According to Conte et al. (1998), some E. huxleyi strains isolated from cold-water regions can grow at $6{ }^{\circ} \mathrm{C}(\mu$ values, $\left.0.3-0.75 \mathrm{~d}^{-1}\right)$, with variation in growth rates among strains. Both MR strains used in this study exhibited marked cold tolerance.

The numbers of calcified and non-calcified (naked) cells of strain MR70N increased logarithmically throughout the early stages of growth (Fig. 1). Around 10-20\% of MR strains were calcified at all temperatures. This finding is similar to the results of Watabe and Wilbur (1966), who reported that $20-50 \%$ of cells were calcified, depending on temperature (a greater proportion of cells were calcified at $24^{\circ} \mathrm{C}$ compared to at $\left\langle 24^{\circ} \mathrm{C}\right.$ ) in Coccolithus huxleyi strain BT-6 (present name, Emiliania huxleyi) isolated from the Sargasso Sea. In contrast to the MR strains, $\sim 50 \%$ of cells in cultures of MS1 and NIES1311 were calcified (Fig. 1e, f). Thus, the calcification abilities of the cold-water strains vary, and MR strains are among the least calcified.

The decrease in cell size with increasing temperature (Figs. 2-4) is consistent with previous reports of E. huxleyi NIES837 (isolated from the Great Barrier Reef, Australia) and E. huxleyi AC481 (isolated from Normandy, France) by Sorrosa et al. (2005) and De Bodt et al. (2010), respec- 
(a)

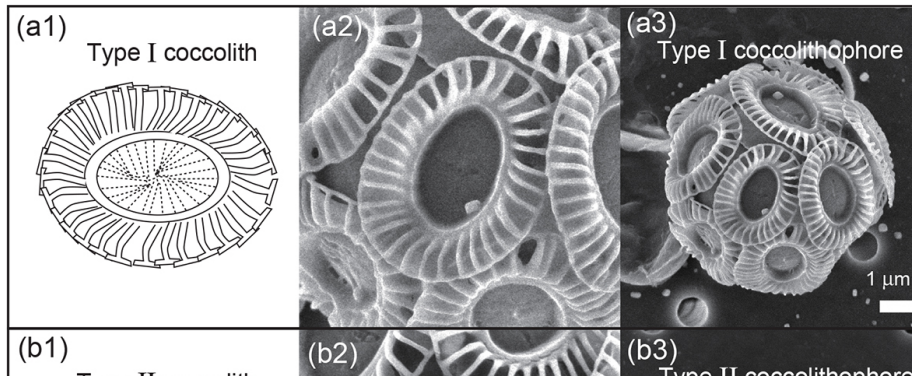

(b)

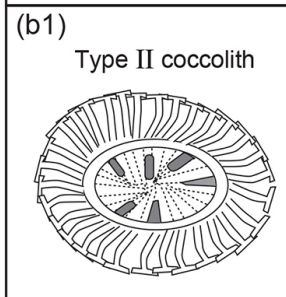

(c)

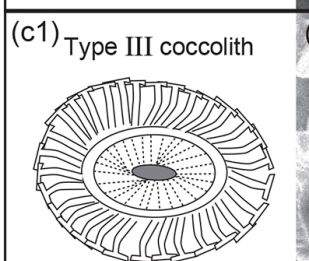

(d)

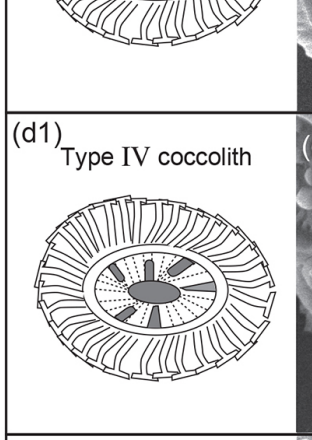

$(\mathrm{e} 1)$

(e)

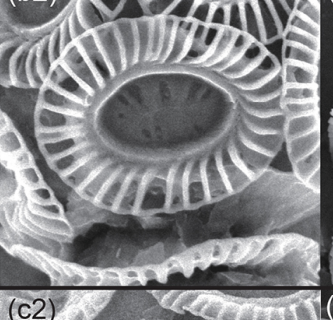

Type II coccolithophore
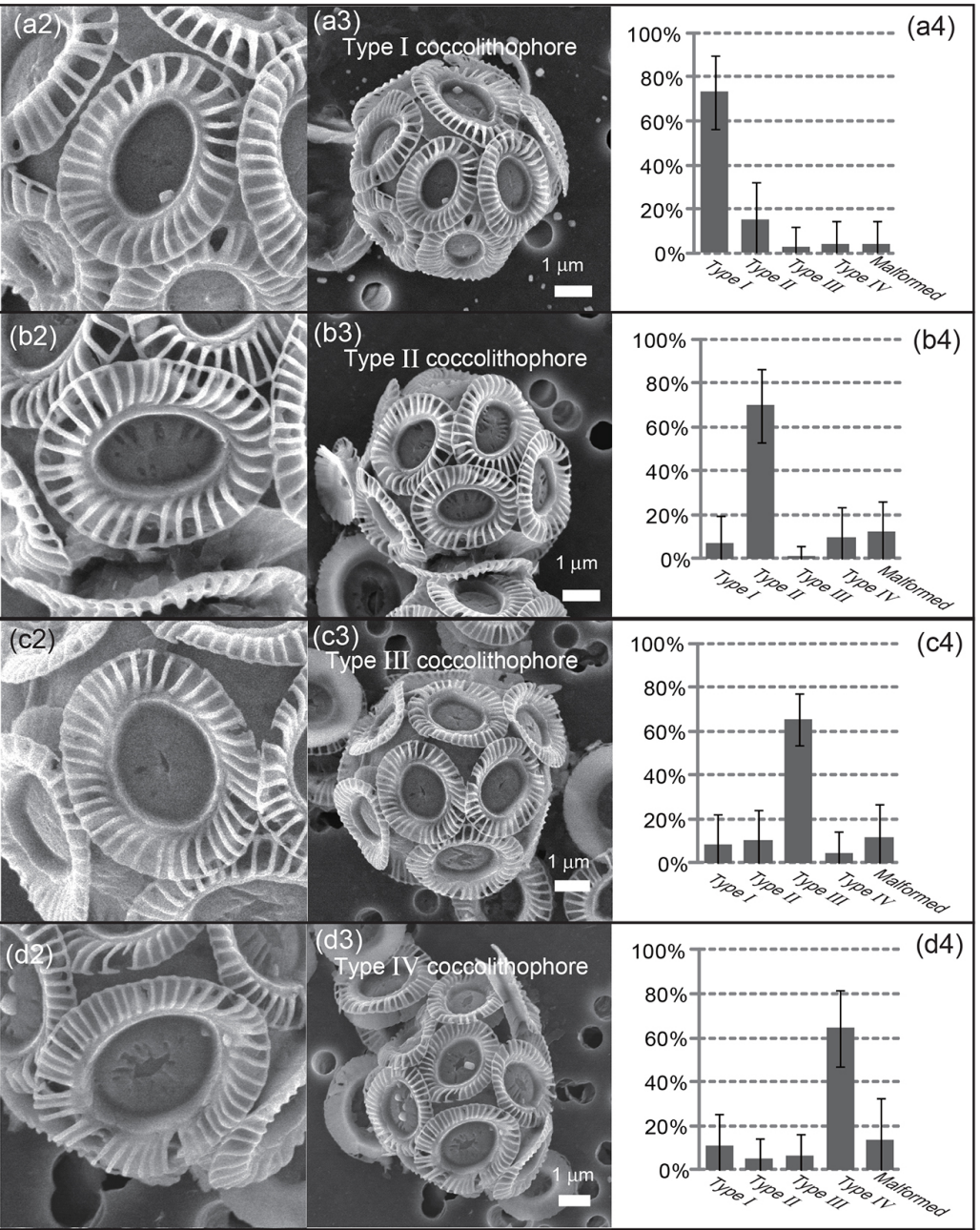

Malformed type
coccolith
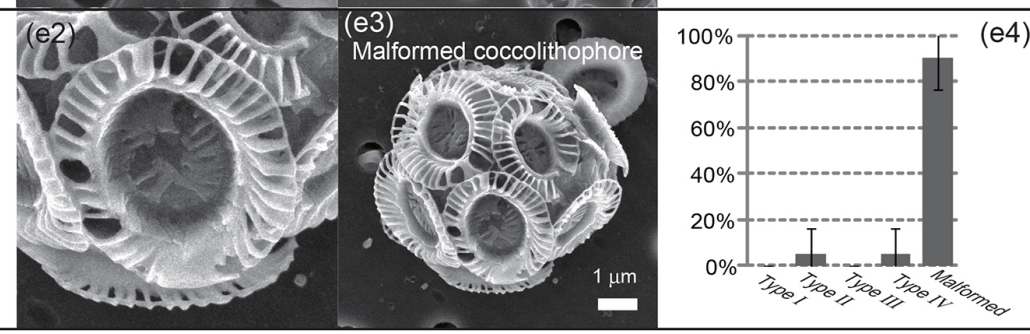

Figure 5. Four submorphotypes (Types I-IV) of MR70N coccoliths, coccolithophores, and malformed cells were categorized by morphology on the basis of SEM images. (a1) Schematic drawing of Type I, whose central area elements are completely calcified, similar to the SEM image shown in (a2). (b1) Schematic of Type II, whose central area elements are partially calcified or with lath-like spaces similar to the SEM image shown in (b2). (c1) Schematic drawing of Type III, whose central area is opened with a hole in the center with well-calcified marginal area, similar to the SEM image shown in (c2). (e1) Schematic drawing of Type IV, whose central area is opened with a hole in the center and a less-calcified marginal area, similar to the SEM image shown in (e2). A SEM image of the malformed type is shown in (e2); the distal shield elements are not well calcified and show an irregular morphology. In (a3) to (e3) are coccolithophore cells of each coccolith type; histograms (a4) to (e4) indicate the proportions of the various coccolith morphotypes (see text).

tively. Calcium uptake in NIES837 strains was higher at lower temperatures (Sorrosa et al., 2005), while E. huxleyi AC481 coccolith morphology and morphometry were unaffected by temperature (De Bodt et al., 2010). Watabe and Wilbur (1966) found a correlation between temperature and coccolith size and growth rate, but not cell diameter. Thus, the temperature dependence of coccolithophore growth and cell size was mostly consistent among the strains, but coccolith formation differed by morphotype. 


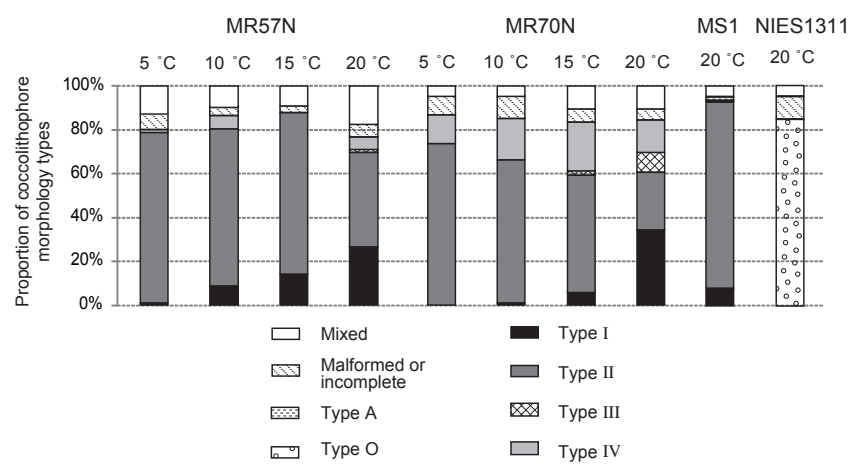

Figure 6. Proportions of morphotypes of coccoliths and coccolithophore cells in E. huxleyi strains MR57N, MR70N, MS1, and NIES1311. Types I-IV: submorphotypes; Types A and O: morphotypes reported previously (see text). Note that morphotype A (Type A) was not observed in strains shown in this figure.

Type I was dominant in MR57N and MR70N cells grown at $5{ }^{\circ} \mathrm{C}$ and $\mathrm{MS} 1$ grown at $20^{\circ} \mathrm{C}$ although Type $\mathrm{O}$ was highly dominant in NIES1311 strain grown at $20^{\circ} \mathrm{C}$ (Fig. 6). Regarding the MR strains, growth rate increased, but cell size and coccolith size decreased, with increasing temperature. All morphometric parameters followed the scaling law. Furthermore, coccolith morphology (such as the central area elements) changed from a completely calcified structure (Type I) at higher temperatures to a partially calcified lath-like structure (Type II) at lower temperatures (Figs. 5, 6). This might be explained by enlargement of the coccolith due to the increased cell diameter (Fig. 3b). Type III and IV coccoliths, which exhibit an open central area (Fig. 5), are similar to coccoliths observed in cells grown under P-limited conditions, as reported by Paasche (1998). In this study, morphometric parameters and morphology of whole cells and coccoliths were examined in cells harvested at the early logarithmic growth phase, as described above. However, in cells harvested at the late logarithmic stage, the proportion of Type II was over $60 \%$ at $5{ }^{\circ} \mathrm{C}$. However, Type IV was increased markedly with increasing temperature, especially high at $20^{\circ} \mathrm{C}$, whereas Type I increased up to $25 \%$ (Fig. 7).

According to Young and Westbroek (1991) and Cook et al. (2011), the width of distal shield elements is also a useful parameter for classifying coccolith morphotypes. The relationship between the width of the distal shield elements and LDS was tested in the MR70N strain (Fig. 4). The MR strains had thin distal shield elements, categorized into Types $\mathrm{B}, \mathrm{B} / \mathrm{C}$, and C. Concerning the ocean-geographical implications of these data, Type $\mathrm{C}$ and $\mathrm{B} / \mathrm{C}$ strains are reported at higher latitudes in cold, sub-Antarctic oceans, while Types A and B were found around the southern Subtropical Front in a warmer-water areas (Patil et al., 2014). In the Bering Sea, the lightly calcified Type A was identified during the bloom that occurred in August 2006 (Harada et al., 2012). Coccolith morphology in various E. huxleyi strains isolated from
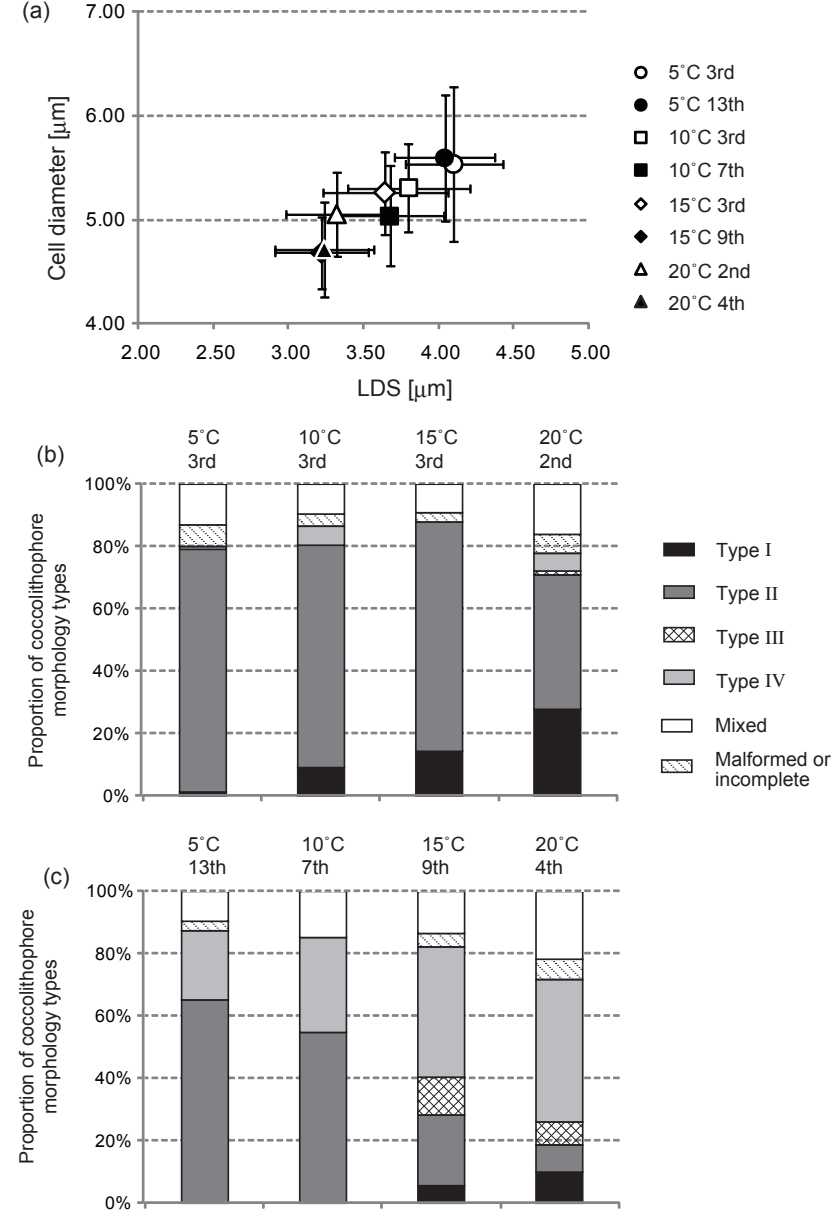

Figure 7. Relationships between LDS and temperature during growth (a) and proportions of morphotypes of coccoliths and coccolithophore cells in E. huxleyi strain MR57N harvested at the early (b) and late (c) logarithmic growth phases. The number below temperature in (b) and (c) indicate the date harvested after initiating culture. For morphotypes, refer to Fig. 5.

various oceanic areas (including in previous reports) is summarized in Table 3. Both the MR57N and MR70N E. huxleyi strains can be categorized as Type $\mathrm{B} / \mathrm{C}$, although both were isolated from cold waters: the Bering Sea and Arctic Sea, respectively.

\subsection{Effects of salinity}

Growth rate increased as salinity decreased from 32 to $26 \%$, which is in part consistent with Passche et al. (1996); however, the growth rates in this study $\left(0.6-0.53 \mathrm{~d}^{-1}\right)$ were markedly lower than those reported by Passche. On the other hand, Fielding et al. (2009) reported an increase in growth rate from 0.05 to $0.7 \mathrm{~d}^{-1}$ with increasing salinity. The lower growth rate in their study might have been caused by use of a lower light intensity than that used by Passche et al. (1996). 
Table 3. List of coccolith morphology of Emiliania huxleyi strains in laboratory culture experiments.

\begin{tabular}{|c|c|c|c|c|c|c|}
\hline $\begin{array}{l}\text { Emiliania huxleyi } \\
\text { strain }\end{array}$ & $\begin{array}{l}\text { Coccolith } \\
\text { morphology }\end{array}$ & $\begin{array}{l}\text { Habitat } \\
\text { isolated }^{\mathrm{a}}\end{array}$ & Temperature & Salinity & $\begin{array}{l}\text { Light } \\
\text { intensity }\end{array}$ & References \\
\hline MR70N & Type B/C & $\mathrm{O}$ & $5,10,15,20$ & $26,32,35$ & $32-34$ & Present study \\
\hline MR57N & Type B/C & $\mathrm{O}$ & $5,10,15,20$ & 32 & $32-34$ & Present study \\
\hline BT6 (CCMP373) & Type $C^{b}$ & $\mathrm{O}$ & $7,12,18,24,27$ & 35 & $\sim 48$ & Watabe and Wilbur (1966) \\
\hline DWN53/74 & - & $\mathrm{O}$ & 20 & 24,34 & 200 & Green et al. (1998) \\
\hline G17779Ga & Type A & $\mathrm{O}$ & 20 & 24,34 & 200 & Green et al. (1998) \\
\hline AC472 & Type R & $\mathrm{O}$ & 18 & 35 & $\sim 100$ & Beaufort et al. (2007) \\
\hline EHSO 5.30 & Type A & $\mathrm{O}$ & 16 & - & 70 & Cook et al. (2011) \\
\hline EHSO 5.25 & Type A & $\mathrm{O}$ & 16 & - & 70 & Cook et al. (2011) \\
\hline EHSO 5.28 & Type A & $\mathrm{O}$ & 16 & - & 70 & Cook et al. (2011) \\
\hline EHSO 5.11 & Type B/C & $\mathrm{O}$ & 16 & - & 70 & Cook et al. (2011) \\
\hline EHSO 6.17 & Type B/C & $\mathrm{O}$ & 16 & - & 70 & Cook et al. (2011) \\
\hline EHSO 8.15 & Type B/C & $\mathrm{O}$ & 16 & - & 70 & Cook et al. (2011) \\
\hline PLY B92/11 & Type A & M & $10,15,20$ & $26-40$ & $\sim 30$ & Fielding et al. (2009) \\
\hline PLY B92/11 & Type A & M & 20 & 24,34 & 200 & Green et al. (1998) \\
\hline OF8 & - & M & 20 & 12 & 200 & Paasche et al. (1996) \\
\hline SC91 & Type $A^{b}$ & M & 20 & $17,25,34$ & 200 & Paasche et al. (1996) \\
\hline AC481 & Type $A^{b}$ & M & 13,18 & 35.6 & 150 & De Bodt et al. (2010) \\
\hline
\end{tabular}

${ }^{a}$ Open $(\mathrm{O})$ or marginal $(\mathrm{M})$ ocean. ${ }^{\mathrm{b}}$ Determined from SEM image published.

The proportion of calcified MR70N cells cultured at $15^{\circ} \mathrm{C}$ decreased markedly when salinity was altered from 32 to either 26 or $35 \%$ (Table 2; Fig. 1g, h). The reduced calcification seems to be similar to the results of Fielding et al. (2009), because a salinity $<26 \%$ did not result in the sufficient production of coccoliths. On the other hand, Passceh et al. (1996) did not observe naked cells, even at $12 \%$ salinity. The coccolith productivity might be affected by the different light intensity used and also the different types of coccolithophore strains.

Cell diameters and coccolith sizes differed slightly (Fig. 8), although there was no correlation between them. The cell diameter was greatest at the lowest salinity, while coccolith size was greatest at the highest salinity; the latter finding is consistent with previous reports (Passche et al., 1996; Fielding et al., 2009). The submorphotypes of larger coccoliths also changed from Type II to Type I. This is consistent with the results of the temperature experiments, and indicates that submorphotype variation might be a strainspecific property.

Previous studies (Passche et al., 1996; Fielding et al., 2009) have considered the original oceanic environment of the strains, for example, coastal/marginal seas or oceans. The morphological and morphometric properties, and the relationships between LDS and temperature and salinity, in MR strains as well as other E. huxleyi strains were graphed together with findings reported previously (Fig. 9). Strains from the open ocean exhibited a strong correlation between LDS and temperature, while those from marginal waters showed a strong correlation between LDS and salinity.

\subsection{Implications for the future polar oceanic environment}

Growth rate and coccolith productivity are important oceanic environmental factors because these affect the biological and physical cycles of the ocean. The carbon cycle is particularly highly affected (Rost and Riebesell, 2004).

Global warming results in an increase in ocean temperature in the polar region, leading to melting of sea ice. This may lead to two scenarios in terms of $E$. huxleyi assemblages, as discussed by Bach et al. (2012). First, the present MR strains may remain dominant in these regions and respond physiologically to the environmental changes. Because two MR strains exhibited growth at $20^{\circ} \mathrm{C}$ to a degree comparable to the other strains and morphotypes (MS1 and NIES1311), this scenario is feasible. In this case, the present data can be directly applied to predict future conditions in the warmer polar region. An increase in the growth rate will result in higher biological activities in this region. Concerning calcification ability, temperature did not affect the proportion of calcified cells (Table 1), but all coccolith morphological parameters decreased with increasing temperature, and followed the scaling law. Thus, an increase in oceanic temperature will result in a reduction in coccolith volume and calcification in this region. The reduced salinity caused by melting sea ice in the Arctic Ocean will facilitate growth of MR strains, the calcification abilities of which will be decreased by the reduction in coccolith production. Thus, higher temperatures and lower salinities will lead to reduced calcification by MR strains in this region. 

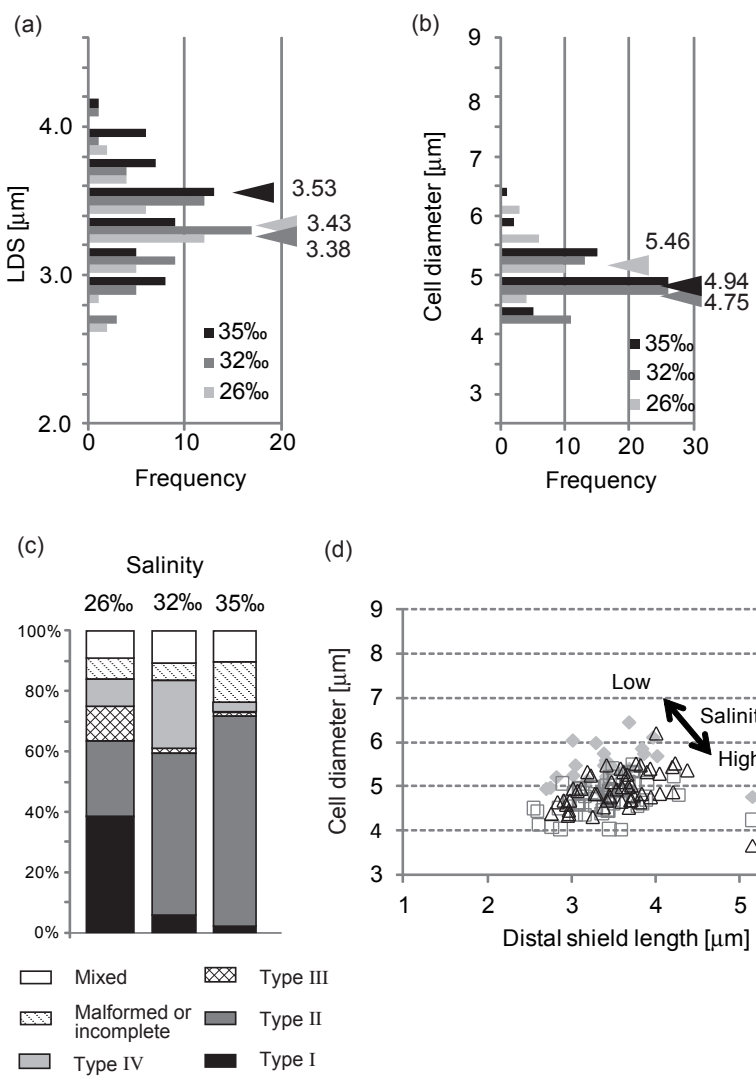

(d)

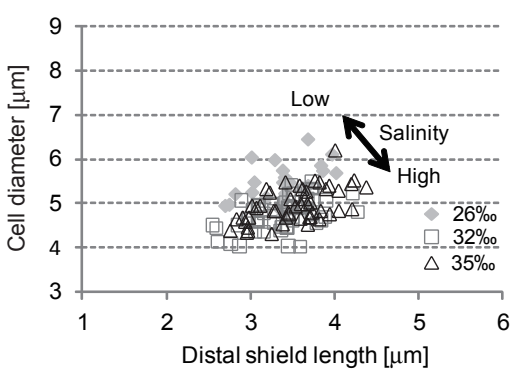

Figure 8. Influence of salinity on the morphometric parameters of E. huxleyi strain MR70N. (a) LDS; (b) cell diameter; (c) proportion of coccolithophore morphotypes; (d) relationship between cell diameter and LDS.

The second scenario is that warmer-type strains or lower salinity-type strains other than MR strains become dominant in this region. According to their morphotype, the Bering Sea and Chukchi Sea E. huxleyi strains (MR57N and MR70N, respectively) can be classified predominantly as Type B/C. Moreover, the majority is of the Type II subtype when cultured at $5{ }^{\circ} \mathrm{C}$, but the population of Type II subtype cells decreases gradually and that of Type I subtype cells increases gradually as temperature is increased to $20^{\circ} \mathrm{C}$. According to Poulton et al. (2011), the Type B/C morphotype has a lower calcite content $(0.011-0.025$ pmol C per coccolith) than Type A (0.015-0.035 pmolC per coccolith). Furthermore, our data indicate that the coccolith productivity of MR strains is lower than that of Type A strains, such as MS1. In the case of the maximum different coccolith productivities between Type A (100\% calcification) and MR strains (15\% calcification), calcite production of Type A and MR strains are estimated as 0.035 and $0.0016 \mathrm{pmol} \mathrm{C}$, respectively. This estimation suggests that the maximum calcification may increase $\sim 20$-fold. On the other hand, if the abundance of lower salinity-type strains increases due the melting of sea ice, coccolith size may also decrease, as reported by Fielding
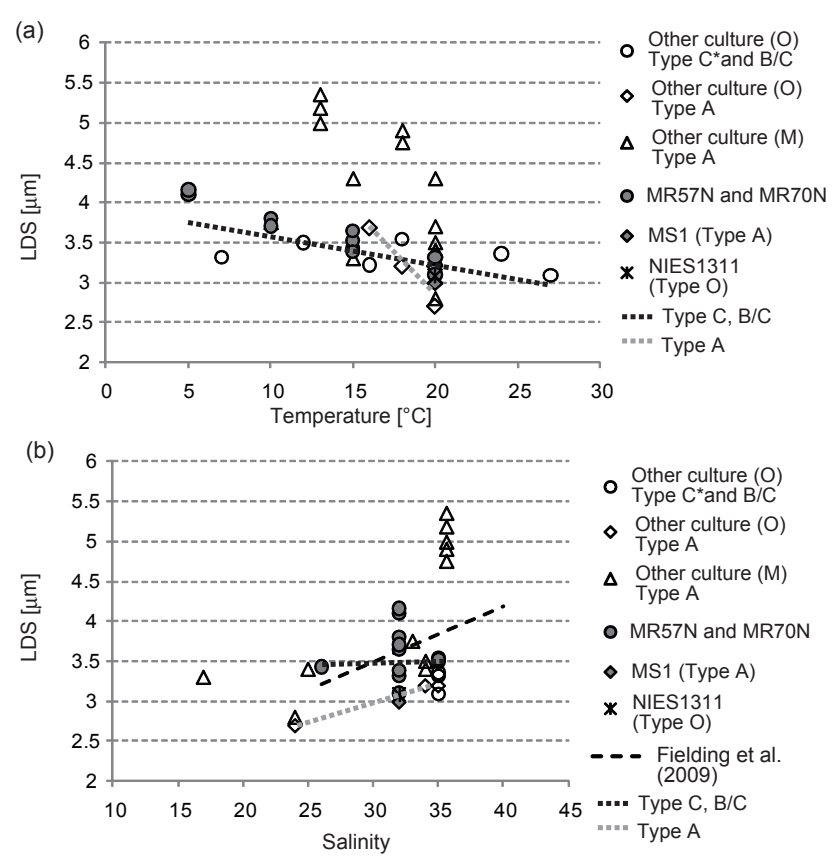

Figure 9. Relationships between LDS and cell diameter changed during growth (a) and LDS and salinity during growth (b) in various strains of E. huxleyi, including MR strains and other strains reported previously.

et al. (2009). However, coccolith productivity may still affect more than the coccolith size reduction and the calcite production will increase about 10-fold from 0.0016 (MR strains) to 0.015 pmol C (smaller Type A) .

Type B/C represents a single, apparently cosmopolitan, population in the Southern Ocean (Cubillos et al., 2007). On the other hand, Triantaphylloue et al. (2010) reported that the size of E. huxleyi coccoliths in the Aegean Sea increased during cooler winter and spring periods. Different strains predominated during the different seasons, similar to the second scenario mentioned above. The morphotype population and the predominant strain in the studied area in the polar region are at present unknown. To facilitate the prediction of future environmental parameters, seasonal and morphotype variation in E. huxleyi should be elucidated.

\section{Conclusions}

Bering Sea and Chukchi Sea coccolithophore strains of $E$. huxleyi are capable of growth at a wide range of temperatures and salinities, and respond differently to different temperature and salinity conditions. We found that temperature affected the growth rates of both strains, and influenced coccolithophore cell size, coccolith size, and coccolith morphology. The MR70N strain exhibited reduced calcification and higher growth rates at lower and higher salinities, respectively, at $15^{\circ} \mathrm{C}$. These results suggest that MR strains can 
adapt to various environments, including the low temperatures and low salinities caused by the melting of sea ice in the Pacific subarctic and Arctic oceans. If these strains become dominant in this region, coccolith productivity will decrease, leading to an increase in the so-called biological pump. On the other hand, if other morphotypes become dominant in this region, calcification productivity will increase, leading to an increase in the biological pump. Thus, investigations of coccolithophores will enhance our understanding of the future environment in the polar region.

Acknowledgements. This study was funded in part by Grants-inAid for Scientific Research (S) from the Japan Society for the Promotion of Science (JSPS) to Yoshihiro Shiraiwa (co-member) and Naomi Harada (Project leader; JFY2010-2014, no. 22221003) and CREST/JST to Yoshihiro Shiraiwa (JFY2010-2015).

Edited by: M. Chierici

\section{References}

Bach, L. T., Bauke, C., Meier, K. J. S., Riebesell, U., and Schulz, K. G.: Influence of changing carbonate chemistry on morphology and weight of coccoliths formed by Emiliania huxleyi, Biogeosciences, 9, 3449-3463, doi:10.5194/bg-9-3449-2012, 2012.

Beaufort, L., Probert, I., and Buchet, N.: Effects of acidification and primary production on coccolith weight: Implications for carbonate transfer from the surface to the deep ocean, Geochem. Geophy. Geosy., 8, Q08011, doi:10.1029/2006GC001493, 2007.

Beaufort, L., Probert, I., de Garidel-Thoron, T., Bendif, E. M., RuizPino, D., Metzl, N., Goyet, C., Buchet, N., Coupel, P., Grelaud, M., Rost, B., Rickaby, R. E. M., and de Vargas, C.: Sensitivity of coccolithophores to carbonate chemistry and ocean acidification, Nature, 476, 80-83, doi:10.1038/nature10295, 2011.

Conte, M. H., Thompson, A., Lesley, D., and Harris, R. P.: Genetic and physiological influences on the alkenone/alkenoate versus growth temperature relationship in Emiliania huxleyi and Gephyrocapsa oceaniabout, Geochim. Cosmochim. Ac., 62, 51-68, doi:10.1016/S0016-7037(97)00327-X, 1998.

Cook, S. S., Whittock, L., Wright, S. W., and Hallegraeff, G. M.: Photosynthetic pigment and genetic differences between two Southern Ocean morphotypes of Emiliania huxleyi (Haptophyta), J. Phycol., 47, 615-626, doi:10.1111/j.1529-8817.2011.00992.x, 2011.

Cubillos, J. C., Wright, S. W., Nash, G., de Salas, M. F., Griffiths. B., Tilbrook, B., Poisson, A., and Hallegraeff, G. M.: Calcification morphotypes of the coccolithophorid Emiliania huxleyi in the Southern Ocean: changes in 2001 to 2006 compared to historical data, Mar. Ecol.-Prog. Ser., 348, 47-54, doi:10.3354/meps07058, 2007.

Danbara, A. and Shiraiwa, Y.: The requirement of selenium for the growth of marine coccolithophorids, Emiliania huxleyi, Gephyrocapsa oceanica and Helladosphaera sp. (Prymnesiophyceae), Plant Cell Physiol., 40, 762-766, 1999.

De Bodt, C., Van Oostende, N., Harlay, J., Sabbe, K., and Chou, L.: Individual and interacting effects of $p \mathrm{CO}_{2}$ and temperature on Emiliania huxleyi calcification: study of the calcite production, the coccolith morphology and the coccosphere size, Biogeosciences, 7, 1401-1412, doi:10.5194/bg-7-1401-2010, 2010.

Fielding, S. R., Herrle, J. O., Bollmann, J., Worden, R. H., and Montagnesd, D. J.: Assessing the applicability of Emiliania huxleyi coccolith morphology as a sea-surface salinity proxy, Limol. Oceanogr., 54, 1475-1480, 2009.

Fujiwara, A., Hirawake, T., Suzuki, K., Imai, I., and Saitoh, S.I.: Timing of sea ice retreat can alter phytoplankton community structure in the western Arctic Ocean, Biogeosciences, 11, 17051716, doi:10.5194/bg-11-1705-2014, 2014.

Green, J. C., Heimdal, B. R., Paasche, E., and Moate, R.: Changes in calcification and the dimensions of coccoliths of Emiliania huxleyi (Haptophyta) grown at reduced salinities, Phycologia, 37, 121-131, doi:10.2216/i0031-8884-37-2-121.1, 1998.

Hagino, K., Bendif, E. M., Young, J. R., Kogame, K., Probert, I., Takano, Y., Horiguchi, T., de Vargas. C., and Okada, H.: New evidence for morphological and genetic variation in the cosmopolitan coccolithophore Emiliania huxleyi (Prymnesiophyceae) from the COX1b-ATP4 genes, J. Phycol., 47, 11641176, doi:10.1111/j.1529-8817.2011.01053.x, 2011.

Harada, N., Sato, M., Oguri, K., Hagino, K., Okazaki, Y., Katsuki, K., Tsuji, Y., Shin, K.-H., Tadai, O., Saitoh, S.-I., Narita, H., Konnno, S., Jordan, R. W., Shiraiwa, Y., and Grebmeier, J.: Enhancement of coccolithophorid blooms in the Bering Sea by recent environmental changes, Global Biogeochem. Cy., 26, GB2036, doi:10.1029/2011GB004177, 2012.

Liu, H., Probert, I., Uitz, J., Claustre, H., Aris-Brosou, S., Frada, M., Not, F., and de Vargasa, C.: Extreme diversity in noncalcifying haptophytes explains a major pigment paradox in open oceans, P. Natl. Acad. Sci. USA, 106, 12803-12808, 2009.

Mantua, N. J., Hare, S. R., Zhang, Y., Wallace, J. M., and Francis, R. C.: A pacific interdecadal climate oscillation with impacts on salmon production, B. Am. Meteorol. Soc., 78, 1069-1079, 1997.

McIntyre, A. and Bé, A. W. H.: Modern coccolithophoridae of the Atlantic Ocean - I. Placoliths and cyrtoliths, Deep-Sea Res., 14, 561-597, doi:10.1016/0011-7471(67)90065-4, 1967.

Noël, M.-H., Kawachi, M., and Inoue, I.: Induced dimorphic life cycle of a coccolithophorid, Calyptrosphaera sphaeroidea (Prymnesiophyceae, Haptophyta), J. Phycol., 40, 112-129, doi:10.1046/j.1529-8817.2004.03053.x, 2004.

Paasche, E.: Roles of nitrogen and phosphorus in coccolith formation in Emiliania huxleyi (Prymnesiophyceae), Eur. J. Phycol., 33, 33-42, doi:10.1080/09670269810001736513, 1998.

Paasche, E.: A review of the coccolithophorid Emiliania huxleyi (Prymnesiophyceae), with particular reference to growth, coccolith formation, and calcification-photosynthesis interactions, Phycologia, 40, 503-529, doi:10.2216/i0031-8884-40-6-503.1, 2001.

Paasche, E., Brubak, S., Skattebøl, S., Young, J. R., and Green, J. C.: Growth and calcification in the coccolithophorid Emiliania huxleyi (Haptophyceae) at low salinities, Phycologia 35, 394403, doi:10.2216/i0031-8884-35-5-394.1, 1996.

Patil, S. M., Mohan, R., Shetye, S., Gazi, S., and Jafar, S.: Morphological variability of Emiliania huxleyi in the Indian sector of the Southern Ocean during the austral summer of 2010, Mar. Micropaleontrol., 107, 44-58, doi:10.1016/j.marmicro.2014.01.005, 2014. 
Post, E., Bhatt, U. S., Bitz, C. M., Brodie, J. F., Fulton, T. L., Hebblewhite, M., Kerby, J., Kutz, S. J., Stirling, I., and Walker, D. A.: Ecological consequences of sea-ice decline, Science, 341, 519, doi:10.1126/science.1235225, 2013.

Poulton, A. J., Young, J. R., Bates, N. R., and Balch, W. M.: Biometry of detached Emiliania huxleyi coccoliths along the Patagonian Shelf, Mar. Ecol.-Prog. Ser., 443, 1-17, doi:10.3354/meps09445, 2011.

Rost, B. and Riebesell, U.: Coccolithophores and the biological pump: responses to environmental changes, in: Coccolithophores: from molecular processes to global impact, edited by: Thierstein, H. R. and Young, J. R., Berlin, Springer, 99-125, 2004.

Satoh, M., Itoh, F., Saruwatari, K., Harada, N., Suzuki, I., and Shiraiwa, Y.: Isolation of new strains of coccolithophore, Emiliania Huxleyi from Arctic Sea and their characterization, in: Program and Abstracts of 3rd international symposium on the Arctic Research, Tokyo, Japan, 14-17 January 2013, 54, 2013.

Sorrosa, J. M., Satoh, M., and Shiraiwa, Y.: Low temperature stimulates cell enlargement and intracellular calcification of coccolithophorids, Mar. Biotechnol., 7, 128-133, doi:10.1007/s10126004-0478-1, 2005.

Triantaphyllou, M., Dimiz, M., Krasakpoulou, E., Malinverno, E., Lianou, V., and Souvermezoglou, E.: Seasonal variation in Emiliania huxleyi coccolith morphology and calcification in the Aegean Sea (eastern Mediterranean), Geobios, 43, 99-110, doi:10.1016/j.geobios.2009.09.002, 2010.
Tsunogai, S., Kusakabe, M., Iizumi, H., Koike, I., and Hattori, A.: Hydrographic features of the deep-water of the Bering Sea: The sea of silica, Deep-Sea Res., 26, 641-659, doi:10.1016/01980149(79)90038-4, 1979.

van Rijssel, M. and Gieskes, W. W. C.: Temperature, light, and the dimethylsulfoniopropionate (DMSP) content of Emiliania huxleyi (Prymnesiophyceae), J. Sea Res., 48, 17-27, 2002.

Wassmann, P., Duarte, C. M., Agustí, S., and Sejr, M. K.: Footprints of climate change in the Arctic marine ecosystem, Glob. Change Biol., 17, 1235-1249, doi:10.1111/j.1365-2486.2010.02311.x, 2011.

Watabe, N. and Wilbur, K. M.: Effects of temperature on growth, calcification, and coccolith form in Coccolithus huxleyi (Coccolithineae), Limol. Oceanogr., 11, 567-575, doi:10.4319/lo.1966.11.4.0567, 1966.

Young, J. R. and Westbroek, P.: Genotypic variation in the coccolithophorid species Emiliania huxleyi, Mar. Micropaleontol., 18, 5-23, doi:10.1016/0377-8398(91)90004-P, 1991.

Young, J. R. and Ziveri, P.: Calculation of coccolith volume and its use in calibration of carbonate flux estimates, Deep-Sea Res. Pt II, 47, 1679-1700, doi:10.1016/S0967-0645(00)00003-5, 2000.

Young, J. R., Geisen, M., Cros, L., Kleijne, A., Sprengel, C., Probert, I., and Ostergaard, J.: A guide to extant coccolithophore taxonomy, J. Nannoplankton Res., 1, 1-125, 2003. 